\title{
Spatial distribution of benthic foraminiferal stable isotopes and dinocyst assemblages in surface sediments of the Trondheimsfjord, central Norway
}

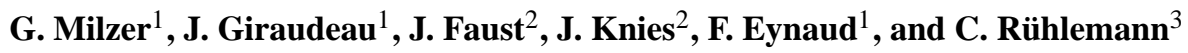 \\ ${ }^{1}$ Université de Bordeaux, CNRS, UMR5805 EPOC, Talence, France \\ ${ }^{2}$ Geological Survey of Norway (NGU), Trondheim, Norway \\ ${ }^{3}$ Federal Institute for Geosciences and Natural Resources (BGR), Hannover, Germany \\ Correspondence to: G. Milzer (g.milzer@epoc.u-bordeaux1.fr)
}

Received: 4 February 2013 - Published in Biogeosciences Discuss.: 26 March 2013

Revised: 22 May 2013 - Accepted: 23 May 2013 - Published: 1 July 2013

\begin{abstract}
Instrumental records from the Norwegian Sea and the Trondheimsfjord show evidence that changes of bottom water temperature and salinity in the fjord are linked to the salinity and temperature variability of the North Atlantic Current (NAC). Changes in primary productivity and salinity in the surface and intermediate water masses in the Trondheimsfjord as well as the fjord sedimentary budget are mainly driven by changes in riverine input. In this study we use 59 surface sediment samples that are evenly distributed in the fjord to examine whether dinocyst assemblages and stable isotope ratios of benthic foraminifera reflect the present-day hydrology and can be used as palaeoceanographic proxies. In general, modern benthic $\delta^{18} \mathrm{O}$ and $\delta^{13} \mathrm{C}$ values decrease from the fjord entrance towards the fjord head with lowest values close to river inlets. This is essentially explained by gradients in the amounts of fresh water and terrigenous organic matter delivered from the hinterland. The distribution of benthic $\delta^{13} \mathrm{C}$ ratios across the fjord is controlled by the origin (terrigenous vs. marine) of organic matter, local topography-induced variability in organic matter flux at the water-sediment interface, and organic matter degradation. The dinocyst assemblages display the variations in hydrography with respect to the prevailing currents, the topography, and the freshwater and nutrient supply from rivers. The strength and depth of the pycnocline in the fjord strongly vary seasonally and thereby affect water mass characteristics as well as nutrient availability, temporally creating local conditions that explain the observed species distribution. Our results prove that dinocyst assemblages and ben-
\end{abstract}

thic foraminiferal isotopes reliably mirror the complex fjord hydrology and can be used as proxies of Holocene climatic variability.

\section{Introduction}

The North Atlantic Current (NAC) is the prolongation of the Gulf Stream and transports warm and saline water northward along the Norwegian continental margin (Ganachaud and Wunsch, 2000). This poleward NAC flow essentially contributes to the deep water formation in the Nordic Seas and strongly affects the northern European climate (Vellinga and Wood, 2002). The hydrology of Norwegian fjords, adjoining the Norwegian Sea, is equally linked to the NAC and the Norwegian Coastal Current (NCC) (Sætre, 1999; Eilertsen and Skarðhamar, 2006; Sætre, 2007). Many fjords have a bedrock threshold at the entrance causing a complex hydrology linked to the ocean currents in the adjacent sea, as well as their salinity and temperature structure, wind dynamics, and riverine input (Inall and Gillibrand, 2010 in Howe et al., 2010). Additionally, fjords are semi-enclosed basins and act as natural sediment traps with high accumulation of marine and terrigenous sediments. As a consequence fjord sediments bear a combined signature of marine, continental and atmospheric environments and processes. Norwegian fjords are therefore excellent locations for high resolution studies of the temporal variations in the physico-chemical characteristics of the NAC and NCC as well as the regional climate 
(Cage and Austin, 2008; Alve et al., 2011). The objective of this study is to examine if micropaleontological proxies deriving from sediments from the Trondheimsfjord reflect the main elements of present-day oceanography and hydrology. The motivation for this examination implies the question to which extent these proxies from fjord sedimentary archives can be used to determine changes in oceanographic regimes in the recent past (Holocene). In order to grasp the complex hydrological and environmental patterns of the bottom and surface waters in the Trondheimsfjord we analysed the stable isotope composition of the benthic foraminifera Melonis barleeanus and organic-walled dinoflagellate cyst assemblages from 59 surface sediment samples evenly distributed along the fjord's axis.

Stable isotope ratios were analysed to determine bottom water characteristics and sediment dynamics in the fjord. Oxygen isotopes in calcite tests are conventional tools for the reconstruction of the past climate since the calcification processes are considered to occur in close equilibrium with the surrounding sea water (e.g. Urey, 1946; and Shackleton and Opdyke, 1973). The foraminiferal ${ }^{18} \mathrm{O} /{ }^{16} \mathrm{O}$ isotope ratio $\left(\delta^{18} \mathrm{O}\right)$ denotes the isotopic composition of the water linked to the salinity and temperature, in which the foraminifera has been ultimately living (e. g. Urey, 1946; Epstein et al., 1953; Shackleton and Opdyke, 1973; and Bemis and Spero, 1998). In coastal environments, however, the relative impact of the freshwater $\delta^{18} \mathrm{O}$ related to the source increases with increasing proximity to the shore (Ingram et al., 1996; Scheurle and Hebbeln, 2003). The carbon isotope ratio in benthic foraminifera is mainly linked to the influence of deep water ventilation, to the origin (marine vs. terrigenous) and the amount of organic matter deposited at the sediment surface, and to remineralization processes in the sediment (e.g. Caralp 1989; Schmiedl et al., 2004; and Fontanier et al., 2008). The stable isotope ratio incorporated in the calcite shell may thus considerably deviate from the isotopic ratio of the bottom water due to fractionation effects, the microhabitat in which the foraminifera lives and calcifies, and the geochemical composition of the associated pore water (Fontanier et al., 2002; Schmiedl et al., 2004).

Dinoflagellate cysts are widely used proxies for the reconstruction of sea-surface conditions in marine and coastal environments (de Vernal et al., 2001; de Vernal and Marret, 2007). Cyst assemblages in marine environments generally reflect surface water characteristics such as temperature, salinity and ice cover. Cyst assemblages in coastal environments are usually tolerant to a wide range of temperatures and salinities and reflect more distinctive ecological preferences such as oceanic versus coastal waters, nutrient availability, salinity gradients as well as stress tolerance to rapid and periodic changes (e.g. Mudie, 1992; Dale et al., 2002; Harland et al., 2004; Radi et al., 2007; and Price and Pospelova, 2011). Dinoflagellate cysts are composed of highly resistant refractory organic matter and generally well preserved in sediments. Some cyst species are, how- ever, more sensitive to post-depositional effects than others, and bottom and pore water oxygenation may alter the original cyst assemblage (Zonneveld et al., 1997, 2007).

Hence, in the following we will investigate benthic stable isotopes and dinocyst assemblages across this particular fjord environment with regard to the hydrological conditions and sediment characteristics.

\section{Physical settings and oceanography}

The following oceanographic and hydrological overview is mainly based on Jacobson (1983) which contains a detailed description of the geomorphology and the main circulation processes affecting the hydrology of the Trondheimsfjord. Moreover, we used monthly hydrographical data and measurements from three mooring stations as well as CTD measurements conducted in April 2011 (Fig. 2) to further illustrate the fjord hydrological context.

The Trondheimsfjord is located at the coast of mid Norway extending from $63^{\circ} 40^{\prime} \mathrm{N}, 09^{\circ} 45^{\prime} \mathrm{E}$ at Ørland to $64^{\circ} 45^{\prime} \mathrm{N}$, $11^{\circ} 30^{\prime} \mathrm{E}$ at the fjord head at Verdal (Bøe et al., 2003) (Fig. 1). The Beitstadfjord adjoins the Trondheimsfjord at Skarnsund $63^{\circ} 50^{\prime} \mathrm{N}, 11^{\circ} 04^{\prime} \mathrm{E}$ and extends until Steinkjer at $63^{\circ} 00^{\prime} \mathrm{N}$, $11^{\circ} 28^{\prime} \mathrm{E}$. The Trondheimsfjord is divided into two basins, the Seaward Basin and the Middle Fjord basin, which are topographically separated from the Norwegian Sea and from each other by bedrock thresholds (Figs. 1, 2a). Stjørnfjord and the Seaward Basin are separated from the Norwegian Sea by a broad and shallow sill at the fjord entrance rising to $195 \mathrm{~m}$ water depth (Fig. 2a). The Tautra Sill with a minimum water depth of $98 \mathrm{~m}$ separates the Seaward Basin from the Middle Fjord (Fig. 2a). The innermost fjord, the Beitstadfjord, is separated from the Trondheimsfjord by the Skarnsund Sill with a minimum water depth of $140 \mathrm{~m}$ (Fig. 2a). The deepest part in the fjord with a maximum water depth of $620 \mathrm{~m}$ is located in the narrow passage between the fjord entrance and Røberg in the Seaward Basin. In the following, unless otherwise specified, the term "Trondheimsfjord" refers to the entire fjord area including Stjørnfjord and Beitstadfjord.

The hydrology of the Trondheimsfjord is linked to the surface current system of the Norwegian Sea which at these latitudes is dominated by the NAC and the brackish coastal waters carried poleward by the NCC. The paths of the NAC and NCC are controlled by the topography of the Norwegian shelf and are the main contributors to the fjord's hydrology (Fig. 1a) (Mork, 1981; Sætre, 1999). The warm and salty poleward NAC affects the top $500 \mathrm{~m}$ of the water column and flows as a slope current with its main core off the shelf break. The NCC flows in the surface layers over the Norwegian shelf and is supplied with brackish water from the Baltic Sea, fjords and rivers along the Norwegian coast (Mork, 1981; Sætre, 1999; Sætre, 2007). The hydrology of the Trondheimsfjord comprises several strongly contrasting 


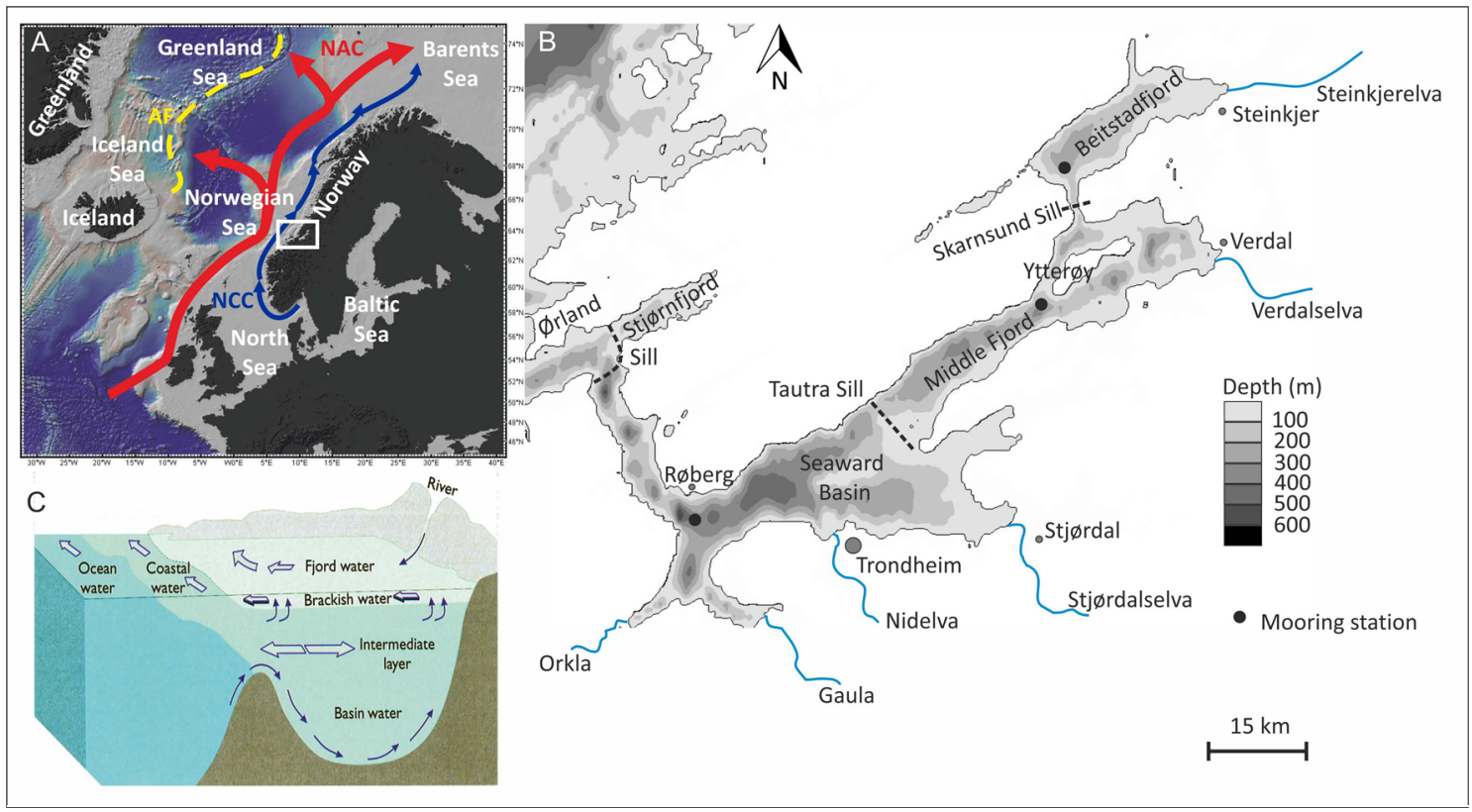

Fig. 1. (A) Surface circulation in the Norwegian Sea; (B) bathymetric map of the Trondheimsfjord. Black dots in the fjord indicate the location of the fixed mooring stations Røberg, Ytterøy and Beitstad referred to in the text; $(\mathbf{C})$ main elements of the surface, intermediate and deep water circulation in Norwegian fjords (from Sætre, 2007).

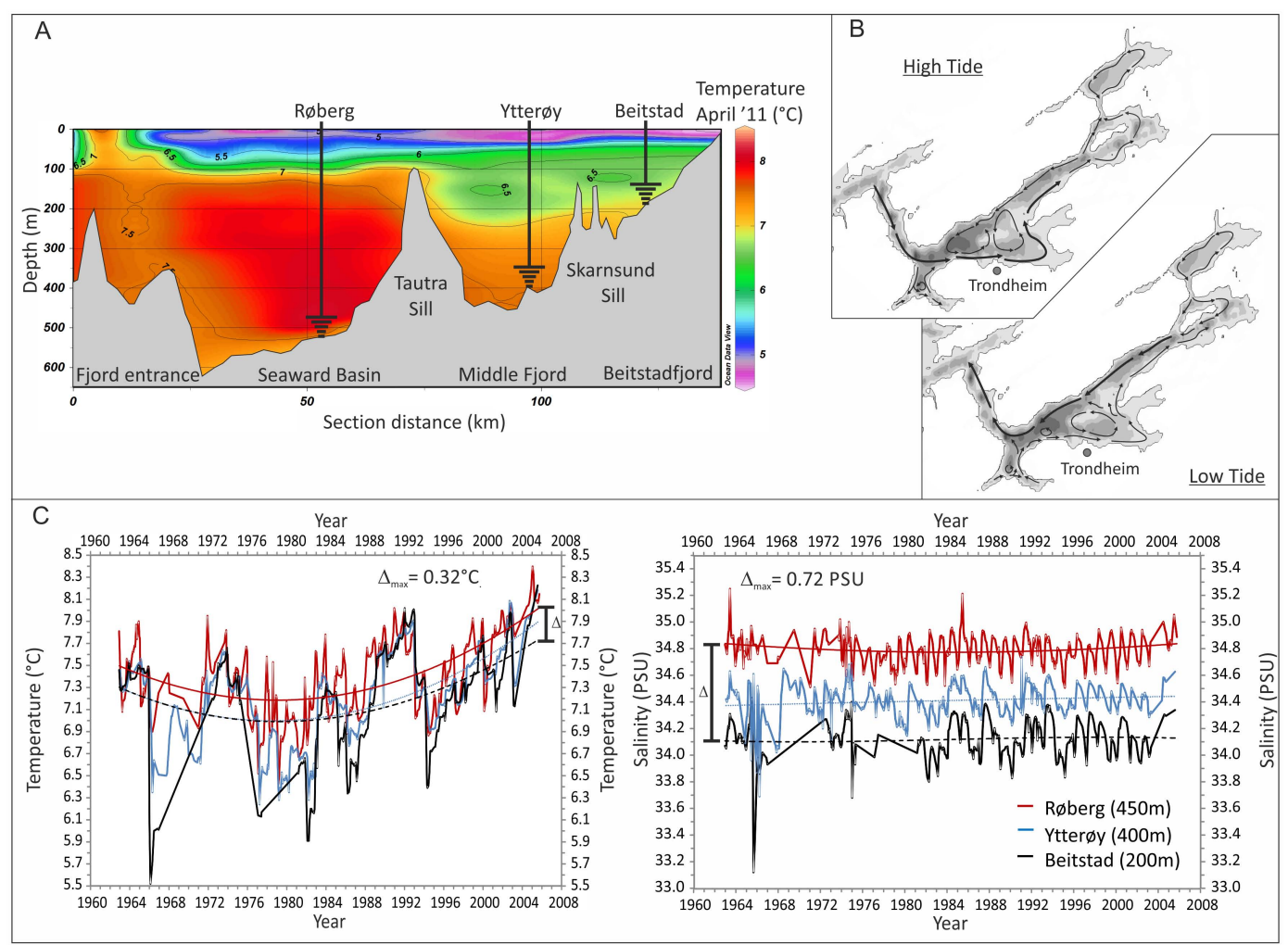

Fig. 2. (A) Water column temperature structure along the fjord axis in April 2011 based on CTD measurements conducted during the sampling cruise of the RV FF Seisma; (B) simplified pattern of the surface circulation during high tide and low tide (after Jacobson, 1983); (C) bottom water temperatures and salinities measured at the fixed mooring stations Røberg, Ytterøy and Beitstad in the Trondheimsfjord from 1963 to 2005 (data from Trondheim Biological Station of the Norwegian University of Science and Technology (NTNU) in Trondheim: http://www.ntnu.edu). 
hydrographic regimes due to the underlying estuarine circulation and high freshwater input mainly from rivers (Fig. 1c) with a total maximum runoff up to $6430 \mathrm{~m}^{3} \mathrm{~s}^{-1}$ during spring flood (Ellingsen, 2004 and references therein; Pettersson, 2012). During high tide surface currents enter the fjord along its southern edge whereas the compensating outflow during low tide circulates along its northern edge (Fig. 2b) (Jacobson, 1983). The fjord entrance and Stjørnfjord are characterized by a more marine/coastal environment (Table 1, Fig. 2). Middle Fjord and Beitstadfjord are more sheltered and largely influenced by the hydrological cycle of the surrounding hinterland resulting in larger temperature and salinity variability (Table 1, Fig. 2). The bottom water renewal in the fjord is controlled by strong seasonal winds of the North Atlantic region and the variability of the pycnocline. In spring (March until June) the NCC is broader and shallower as the result of increasing northerly winds and increased melt water supply from rivers and fjords (Sætre et al., 1988; Sætre, 2007). The reduced vertical extension of the NCC on the inner shelf enables high salinity NAC water to pass over the sill at the fjord entrance and to replace old fjord water from depths deeper than $50 \mathrm{~m}$. Brackish surface water resulting from the peak spring river inputs into the Trondheimsfjord moves seaward compensating the intermediate and deep marine inflow. Starting in late summer/early autumn, south-westerly winds across the Norwegian Sea induce downwelling of the surface layers causing the vertical expansion of the NCC (Sætre et al., 1988; Sætre, 2007). Marine brackish water (NCC) enters the fjord at intermediate depth $(20-70 \mathrm{~m})$ and is quickly mixed into the bottom water. Intense cooling and associated downwelling of the surface and intermediate layers starting in late summer contribute to the process of vertical mixing of the water column in the fjord. According to instrumental measurements, the residence time for upper low salinity surface water is approximately one month, whereas deep water is usually renewed twice a year resulting in a generally well-oxygenated fjord environment during the whole year (Jacobson, 1983).

Water mass characteristics of the intermediate and surface layers vary seasonally with increasing salinity variability towards the inner fjord (according to data from Trondheim Biological Station, NTNU Trondheim) (Table 1). Bottom water temperatures at all stations are relatively stable during the year with an average temperature of $7.3^{\circ} \mathrm{C}$. Bottom water salinities vary seasonally and spatially with annual average salinity ranging between 34.1 and 34.8 PSU from the fjord head towards the fjord entrance (Fig. 2). Nutrient availability and primary production in the Trondheimsfjord are directly linked to the nutrient content and the chlorophyll $a$ concentration in the coastal waters, and in the river water (Sakshaug and Myklestad, 1973; Strømgren, 1974; Bagøien et al., 2012). Annual primary production rates in Norwegian fjords and coastal waters range from 110 to $140 \mathrm{~g} \mathrm{C} \mathrm{m}^{-2} \mathrm{yr}^{-1}, 60 \%$ taking place after the spring bloom during March and April (Erga et al., 2005; Aure et al., 2007 and references therein).

\section{Material and methods}

\subsection{Sample material}

In total, 59 surface sediment samples, evenly distributed along the axis of the Trondheimsfjord (Fig. 4), were collected with a multicorer with 4 tubes as part of a research cruise of the RV FF Seisma (Geological Survey of Norway (NGU), Trondheim) in April 2011. On average, 3 to 4 cores were retrieved at each sample location for micropaleontological analysis at EPOC (CNRS/Université Bordeaux1), and geochemical analysis accomplished at the NGU in Trondheim. Each core was ca. 20 to $40 \mathrm{~cm}$ long and immediately sampled onboard. This study was performed on the top $2 \mathrm{~cm}$ of the sedimentary sections for both stable isotope measurements and dinoflagellate cyst census counts. Present sedimentation rates in the Trondheimsfjord largely vary around $1-5 \mathrm{~mm} \mathrm{yr}^{-1}$ depending on the location (Bøe et al., 2003 and references therein). Regarding these sedimentation rates our surface sediment samples are assumed to integrate 4 to $20 \mathrm{yr}$ of sediment accumulation.

\subsection{Stable isotope measurements}

For each station $18-20 \mathrm{~g}$ of wet bulk sediment were wet sieved using a $63 \mu \mathrm{m}$ mesh size. The residue was ultimately flushed with distilled water and oven-dried at $40^{\circ} \mathrm{C}$. We selected pristine specimens of Melonis barleeanus of similar test size from the $200-350 \mu \mathrm{m}$ fraction to avoid bias caused by physiological effects due to size-related changes in growth rate on the stable isotope variability (Corliss et al., 2002). For each measurement 50-100 $\mu$ g (ca. 3-4 specimens) were prepared. The samples were chemically treated by an automatic carbonate preparation device (Kiel device) and measured with a mass spectrometer type Optima hosted at EPOC (Université Bordeaux 1/CNRS). The instrumental precision yields $0.005 \%$ o for $\delta^{13} \mathrm{C}$ and $0.008 \%$ ofor $\delta^{18} \mathrm{O}$. The stable isotope ratios were calibrated against the Vienna Pee Dee Belemnite (VPDB) using the international standard NBS 19 and are displayed in the $\delta$ notation. Melonis barleeanus is an intermediate infaunal foraminifera $(2-5 \mathrm{~cm})$ which vertically migrates in the sediment depending on the amount and quality of organic matter and the sediment oxygenation (Caralp, 1989; Schmiedl et al., 2004; Fontanier et al., 2006; Fontanier et al., 2008). Investigations on the microhabitat preferences of M.barleeanus in the Golf of Lions (France) (Schmiedl et al., 2000; Fontanier et al., 2008) and in the Bay of Biscay (France) (e.g. Fontanier et al., 2002; and Fontanier, 2006) record an average living depth (ALD) in the upper $3 \mathrm{~cm}$ with a large spatial variability. Sediment accumulation in the Trondheimsfjord strongly varies $\left(1-5 \mathrm{~mm} \mathrm{yr}^{-1}\right)$ with regard to the local topography, complicating an accurate estimation of the ALD and an associated correction of the stable isotope ratios. We therefore corrected only the species-specific deviation of the oxygen isotope ratio due to equilibrium 
Table 1. Minimum, maximum and mean winter and summer temperatures and salinites of surface waters at the mooring stations Røberg, Ytterøy and Beitstad from 1963 to 2005 (Trondheim Biological Station/NTNU Trondheim: http://www.ntnu.edu)

\begin{tabular}{|c|c|c|c|c|c|c|c|}
\hline \multirow[b]{2}{*}{ Season } & \multirow[b]{2}{*}{ Range } & \multicolumn{2}{|c|}{ Røberg } & \multicolumn{2}{|c|}{ Ytterøy } & \multicolumn{2}{|c|}{ Beitstad } \\
\hline & & $\mathrm{T}\left({ }^{\circ} \mathrm{C}\right)$ & S (PSU) & $\mathrm{T}\left({ }^{\circ} \mathrm{C}\right)$ & S (PSU) & $\mathrm{T}\left({ }^{\circ} \mathrm{C}\right)$ & $\mathrm{S}$ (PSU) \\
\hline \multirow{3}{*}{ Winter } & $\min$. & 1.0 & 27.9 & 2.1 & 26.3 & 1.2 & 14.9 \\
\hline & $\max$ & 8.3 & 34.1 & 8.0 & 34.0 & 8.2 & 33.7 \\
\hline & mean & 4.9 & 32.5 & 4.4 & 32.1 & 5.1 & 31.3 \\
\hline \multirow{3}{*}{ Summer } & $\min$. & 5.7 & 22.6 & 5.6 & 20.3 & 5.3 & 18.4 \\
\hline & $\max$ & 17.5 & 33.9 & 18.3 & 33.8 & 17.4 & 33.7 \\
\hline & mean & 11.0 & 30.9 & 10.5 & 30.4 & 10.4 & 29.4 \\
\hline
\end{tabular}

fractionation between the calcite shell and the bottom water, the so-called vital effect (e.g. Woodruff et al., 1980; McCorkle et al., 1990; Holsten et al., 2004; and Schmiedl et al., 2004) by a constant value of $+0.4 \%$ according to studies of M. barleeanus in the Norwegian Sea (e.g. Woodruff et al., 1980; Graham et al., 1981; and Jansen et al., 1989). With regard to the complex interaction of organic matter flux, degradation and sediment depth we did not apply any correction value for the $\delta^{13} \mathrm{C}$.

\subsection{Dinocyst assemblages}

Dinoflagellate cysts were retrieved from the $<150 \mu \mathrm{m}$ fraction. The preparation technique follows a standard sample preparation procedure (e.g. Stockmarr 1971; and de Vernal et al., 1996) slightly modified at EPOC/Université Bordeaux1 (Penaud et al., 2010). For the purpose of quantification and calculation of the cyst concentrations, spores of Lycopodium clavatum were added prior to the sample treatment (e.g. Stockmarr, 1971). The samples were successively treated with cold 10, 25 and 50\% hydrochloric acid (HCL) and cold 40 and $70 \%$ hydrogen fluoride (HF) and again with $25 \%$ HCL. The residue was sieved through $10 \mathrm{~mm}$ nylon mesh screens. Since high amounts of amorphous organic material (AOM) concealed the cysts as well as their spines and processes we carefully removed any resistant AOM by centrifugation and swirling in a large watch glass. The method relies on density differences between the cysts and the AOM (Riding and Kyffin-Hughes, 2004; L. Londeix, personal communication, 2012). Cyst counts of various samples before and after the treatment show only minor discrepancies: counting of the untreated samples yield lower amounts of the smaller species Pentapharsodinium dalei and randomly a stronger presence of Selenopemphix quanta due to the different dimensions of the cyst bodies. We assume that the relative amount of the dominant species $P$. dalei masked by AOM causes a stronger permanent variation of the cyst assemblages than randomly higher amounts of $S$. quanta. Still, we keep in mind a potential increase in the abundance of certain species characterized by larger cyst bodies.
The residue containing the dinocysts was mounted between slide and coverslip with glycerine jelly. An average amount of 300 cysts per slide was counted using a Zeiss axio scope light microscope at $40 \times$ magnification. The identification of the cysts is based on the nomenclature of Rochon et al. (1999) and Head et al. (2001). Operculodinium centrocarpum s.l. includes both, long-process and short-process forms of $O$. centrocarpum sensu Wall and Dale (1967) and O. centrocarpum - Arctic morphotype (de Vernal et al., 2001). Dinoflagellate species within the Spiniferites group are grouped according to Marret and Zonneveld (2003). Hence, Spiniferites elongatus s.l. includes Spiniferites elongatus and Spiniferites frigidus, and Spiniferites membranaceus includes Spiniferites belerius. Spiniferites ramosus comprises species of Spiniferites bulloides, and Spiniferites hyperacanthus is grouped together with species of Spiniferites mirabilis. Spiniferites spp. refers to every cyst that is clearly recognized as a species of the Spiniferites assemblage but is not identified beyond the genus level. S. quanta includes Selenopemphix nephroides (Marret and Zonneveld, 2003). Islandinium minutum includes Islandinium cezare and Brigantedinium spp. includes Brigantedinium simplex and Brigantedinium caracoense. Impagidinium spp. includes the species Impagidinium patulum, Impagidinium aceulatum and Impagidinium sphaericum (Marret and Zonneveld, 2003). Census counts of the cysts are expressed as both relative (\%) and absolute abundances (cysts $\mathrm{cm}^{-3}$ ) (Fig. 5).

The cyst counts were statistically evaluated using nonmetric multidimensional scaling (NMDS) based on BrayCurtis dissimilarities and visualization in a two-dimensional space to check for any groupings within the study area (Holland, 2008). We accomplished the analysis using the free software package R 2.15.1 (http://cran.r-project.org/). Before running the NMDS the data set was square root transformed and submitted to Wisconsin double standardization due to the large range of data values. 


\section{Results and discussion}

\subsection{Benthic oxygen isotopes}

Oxygen isotope ratios of $M$. barleeanus range between 0.39 and $2.14 \%$ with a mean value of $1.2 \%$ (Figs. 3a, 4). Overall, the foraminiferal $\delta^{18} \mathrm{O}$ values decrease along the Trondheimsfjord from the fjord entrance $(2.1 \%$ ) to the fjord head $(0.6 \%) . \delta^{18} \mathrm{O}$ values in the Seaward Basin are higher than in the Middle Fjord (Fig. 3a). At the Tautra Sill, which separates the two basins, $\delta^{18} \mathrm{O}$ markedly increases by $0.5 \%$ as compared to the values inwards and seawards of this bedrock threshold (Fig. 4). The strongest deviations from the mean value of $1.2 \%$ were determined for samples recovered from the side branch south-east of the Tautra Sill (M304: 0.56\%o, M305: $0.48 \%$ o) and the shallow bay in the central Middle Fjord (M214: 0.39\%o) (Fig. 3a). Oxygen isotopes from the southernmost part of the fjord, where the rivers Orkla and Gaula discharge fresh water, do not deviate remarkably from the mean, in contrast to other sites close to the mouths of the rivers Stjørdalselva and Nidelva (Fig. 3a).

The $\delta^{18} \mathrm{O}$ ratio in foraminiferal calcite shells is predominantly controlled by the temperature and $\delta^{18} \mathrm{O}$ of the ambient seawater (e.g. Urey, 1946; and Shackleton and Opdyke, 1973). Measurements from the Sognefjord, located some 400 $\mathrm{km}$ south of the Trondheimsfjord, show that the $\delta^{18} \mathrm{O}$ of the water $\left(\delta^{18} \mathrm{O}_{\mathrm{w}}\right)$ is positively related to salinity as both, $\delta^{18} \mathrm{O}_{\mathrm{w}}$ and salinity, are mainly controlled by the admixture of ${ }^{18} \mathrm{O}$-depleted fresh water supplied by rivers and groundwater (Mikalsen and Sejrup, 2000). Sognefjord, like the Trondheimsfjord, is separated from the Norwegian shelf by sills, largely controlled by the NAC and NCC, and is supplied with large amounts of ${ }^{18} \mathrm{O}$-depleted river water and groundwater from the Norwegian hinterland (Jacobson, 1983; Mikalsen and Sejrup 2000). Bottom water temperatures and salinities recorded along the Trondheimsfjord tend to increase from the fjord head towards the fjord entrance as documented by our own measurements during the sampling cruise in April 2011 and the $43 \mathrm{yr}$-long monthly to bimonthly records of three mooring stations located in each basin (Fig. 2a). This spatial pattern in temperature and salinity is independent from season or year (Fig. 2c). If temperature was the predominant factor controlling the foraminiferal $\delta^{18} \mathrm{O}$ in the Trondheimsfjord, a decrease towards the fjord entrance would be expected because of the inverse relationship between temperature and $\delta^{18} \mathrm{O}_{\text {calcite }}$ (e.g. Shackleton and Opdyke, 1973; Bemis and Spero, 1998; and Mulitza et al., 2003). This is clearly at odds with our data (Figs. 3a, 4). We therefore assume that the spatial distribution of benthic foraminiferal $\delta^{18} \mathrm{O}$ primarily reflects the decrease in salinity and $\delta^{18} \mathrm{O}_{\mathrm{w}}$ with increasing distance from the fjord entrance as a consequence of increasing brackish water supply towards the fjord head.

The influence of temperature and salinity on the $\delta^{18} \mathrm{O}$ in the calcite shell, however, depends on the species (vital effect and habitat effect) (e.g. Shackleton and Opdyke, 1973; and Bemis and Spero, 1998) and the seasonal effect, particularly in coastal environments (Cage and Austin, 2008). According to several previous studies (e.g. Caralp, 1989; Mackensen et al., 2000; Alve, 2010; and Alve et al., 2011), M. barleeanus is not an opportunistic species and does not calcify during a certain time of the year. Considering the life cycle of $M$. barleeanus as well as the period of 4-20 $\mathrm{yr}$ integrated in the investigated surface sediment samples, it is likely that the oxygen isotope ratios record the temperature and salinity variability over different time periods. Our interpretation of the benthic $\delta^{18} \mathrm{O}$ distribution in the Trondheimsfjord does not take into consideration any effect on the foraminiferal $\delta^{18} \mathrm{O}$ due to the topographic settings, tidal currents, erosion or remobilization of the sediment induced by strong currents (Bøe et al., 2003), and the age variability of surface samples, which all together account for the patchiness of the recorded $\delta^{18} \mathrm{O}$ ratios. Nevertheless, regarding the relatively stable physico-chemical conditions in the Trondheimsfjord (Fig. 2c) the spatial trend of the benthic $\delta^{18} \mathrm{O}$ along the fjord axis (Figs. 3a, 4) can be certainly addressed to the decrease of salinity with increasing distance from the fjord's entrance.

\subsection{Benthic carbon isotopes}

The carbon isotope ratios of the infaunal benthic foraminifera M. barleeanus show a patchy distribution with an overall decreasing trend from the fjord entrance to the fjord head, ranging between -0.28 and $-2.65 \%$ with a mean value of $-1.37 \%$ (Figs. 3b, 4). Beside the $\delta^{13} \mathrm{C}$ ratios at the fjord entrance, the highest ratios were measured in samples close to the Tautra Sill. The $\delta^{13} \mathrm{C}$ ratios within the fjord basins are lower with an average ratio of $-1.6 \%$.

Several studies on the ecological preferences of M. barleeanus have shown that the occurrence of this species is linked to the quality of organic matter deposited in the sediment (Caralp, 1989; Mackensen et al., 2000; Schmiedl and Mackensen, 2006; Alve, 2010; Alve et al. 2011). The species prefers organic matter in a more altered form, and migrates in the sediment depending on the organic matter supply and remineralization (Caralp, 1989; Mackensen et al., 2000; Schmiedl and Mackensen, 2006). The organic matter decomposition is dependent on the source of the organic matter itself, the oxygen penetration depth, and thus the sediment accumulation rate, the substrate composition and bioturbation. The decomposition of organic matter results in an enhanced accumulation of ${ }^{12} \mathrm{C}$ enriched carbon which is added to the pore water and ultimately incorporated in the calcite shell of M. barleeanus (Schmiedl et al., 2000, 2004; Loubere et al., 2011). Consequently, the $\delta^{13} \mathrm{C}$ ratio in the living $M$. barleeanus decreases with increasing sediment depth related to the pore water $\delta^{13} \mathrm{C}_{\text {DIC }}$ (dissolved inorganic carbon), that exponentially decreases within the uppermost sediment (McCorkle et al., 1985; Grossmann, 1987; Mackensen et al., 2000). 

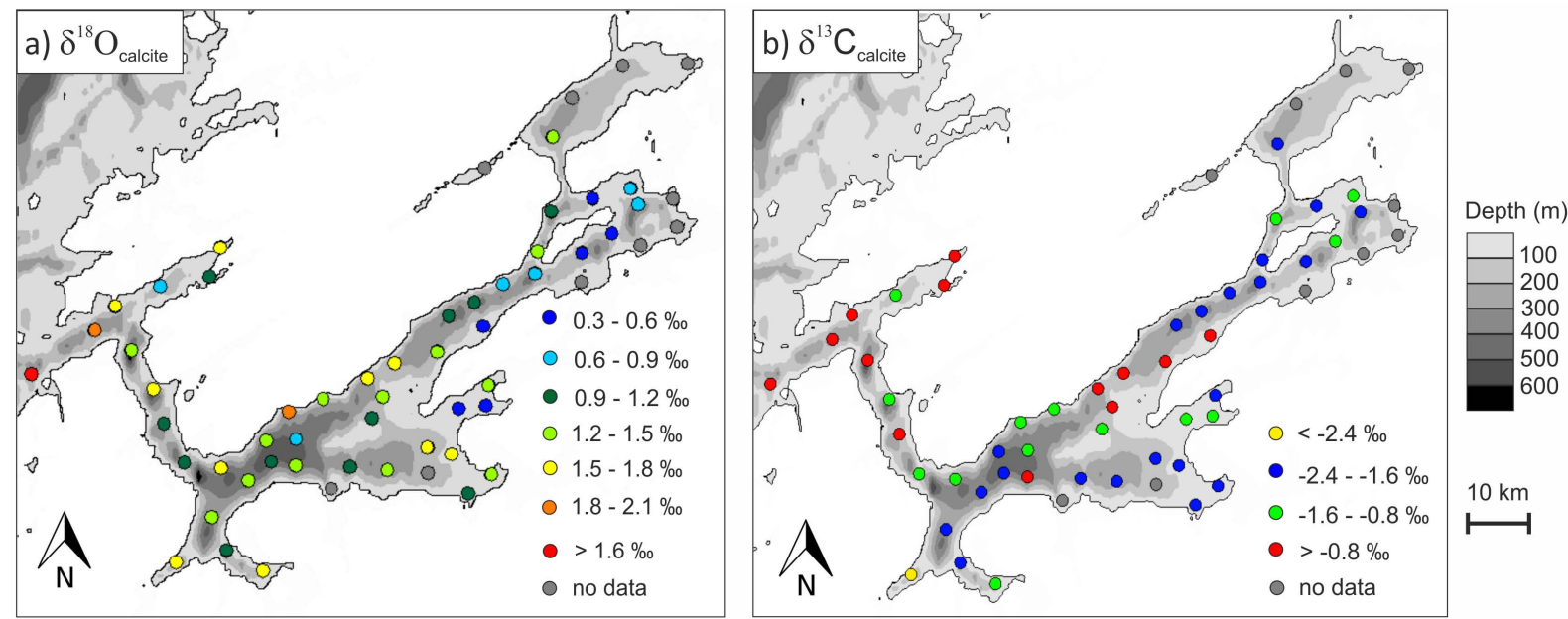

Fig. 3. Benthic foraminiferal (M. barleeanus) stable isotope distribution in the Trondheimsfjord: (a) $\delta^{18} \mathrm{O} ;(\mathbf{b}) \delta^{13} \mathrm{C}$.

Sediment and organic matter deposition in the Trondheimsfjord is largely controlled by the bottom currents and the topography resulting in a strong spatial variability in sediment accumulation rates, substrate composition, organic matter fluxes and oxygen availability (Bøe et al. 2003). Moreover, proximity to river inlets and slope instabilities significantly affect the fjord sediments and the associated microhabitat of the organisms living therein, and ultimately the observed benthic $\delta^{13} \mathrm{C}$ ratios in the fjord. Hence, in addition to $\delta^{13} \mathrm{C}$ variability induced by deep water ventilation, the benthic carbon isotope ratios in $M$. barleeanus are strongly related to the microhabitat and pore water geochemistry at each study site.

Regardless of species-specific microhabitat and ecological preferences, benthic foraminiferal $\delta^{13} \mathrm{C}$ in coastal and estuarine environments is used as tracer of the relative influence of marine vs. fresh waters, especially in high latitude regions which are affected by strong seasonal changes in river runoff (Polyak et al., 2003; Bauch et al., 2004). Dissolved inorganic carbon in rivers originates mainly from the degradation of ${ }^{12} \mathrm{C}$-enriched organic matter from continental soils, resulting in generally lower $\delta^{13} \mathrm{C}$ values as compared to marine water. Regarding the large amounts of fresh water and terrigenous material being temporally discharged into the Trondheimsfjord the overall decreasing trend in benthic foraminiferal $\delta^{13} \mathrm{C}$ along the Trondheimsfjord axis (Fig. 4) and in the side branches (Fig. 3b) is likely to reflect the $\delta^{13} \mathrm{C}_{\text {DIC }}$ gradient between river and marine-derived waters. The measured foraminiferal $\delta^{13} \mathrm{C}$ gradient of ca. $1 \%$ o between the fjord entrance and the fjord head (Fig. 4) is, however, 5 times larger than the estimated $\delta^{13} \mathrm{C}_{\text {DIC }}$ gradient per ca. 1 PSU bottom salinity difference for this high latitude setting (Erlenkeuser et al., 1999; Polyak et al., 2003). Hence, additionally to the freshwater supply, enhanced terrigenous organic matter flux and remineralization close to river inlets in the side branches of the fjord basins and at the fjord head clearly affect the $\delta^{13} \mathrm{C}_{\mathrm{DIC}}$ of the bottom water and may explain the observed benthic foraminiferal $\delta^{13} \mathrm{C}$ gradient in the Trondheimsfjord. Measured ratios of total organic carbon vs. organic nitrogen $(\mathrm{C} / \mathrm{N})$ in the fjord surface sediments confirm the progressively enhanced contribution of terrigenous vs. marine organic matter with distance from the sea and with proximity to major river inlets (J. Faust, personal communication, 2012).

We explain the observed peak $\delta^{13} \mathrm{C}$ excursions in surface sediments close to the Tautra Sill (Fig. 4) by differences in sediment accumulation between shallow and deep settings. As summarized by Jacobson (1983), prevalent (tidal) currents in the subsurface layers at the sills in the Trondheimsfjord reach maximum velocities up to $100 \mathrm{~cm} \mathrm{~s}^{-1}$. The strength of these tidal currents impedes the accumulation of fine sediments $(<63 \mu \mathrm{m})$ and organic matter on the sills. Instead fine grained sedimentation rather occurs in the deep and more sheltered areas of the fjord basins (Dale, 1976). Low organic matter concentrations in the sediments at shallow sites such as the Tautra Sill result in (1) a shallower microhabitat of $M$. barleeanus and (2) in reduced release of isotopically depleted $\mathrm{CO}_{2}$ during organic matter degradation causing a relative increase of the $\delta^{13} \mathrm{C}$ ratio. The same process might explain the observed heavy benthic $\delta^{13} \mathrm{C}$ at the relatively shallow fjord entrance (Stjørnfjord) and at the sill (Fig. 3b), in addition to the dominant influence of marine waters and thus enhanced $\delta^{13} \mathrm{C}_{\text {DIC }}$ (Polyak et al., 2003; Bauch et al., 2004; Filipsson et al., 2004).

Our results indicate that the distribution of benthic foraminiferal $\delta^{13} \mathrm{C}$ in the Trondheimsfjord reflects the $\delta^{13} \mathrm{C}_{\mathrm{DIC}}$ gradient between marine and river-derived waters and the associated differences in $\delta^{13} \mathrm{C}$ of continental vs. marine organic matter. Deviations from this pattern are caused by local, topography-related variations of organic matter accumulation and degradation in the bottom sediment, and the related geochemical composition of the bottom and pore waters at each study site. 

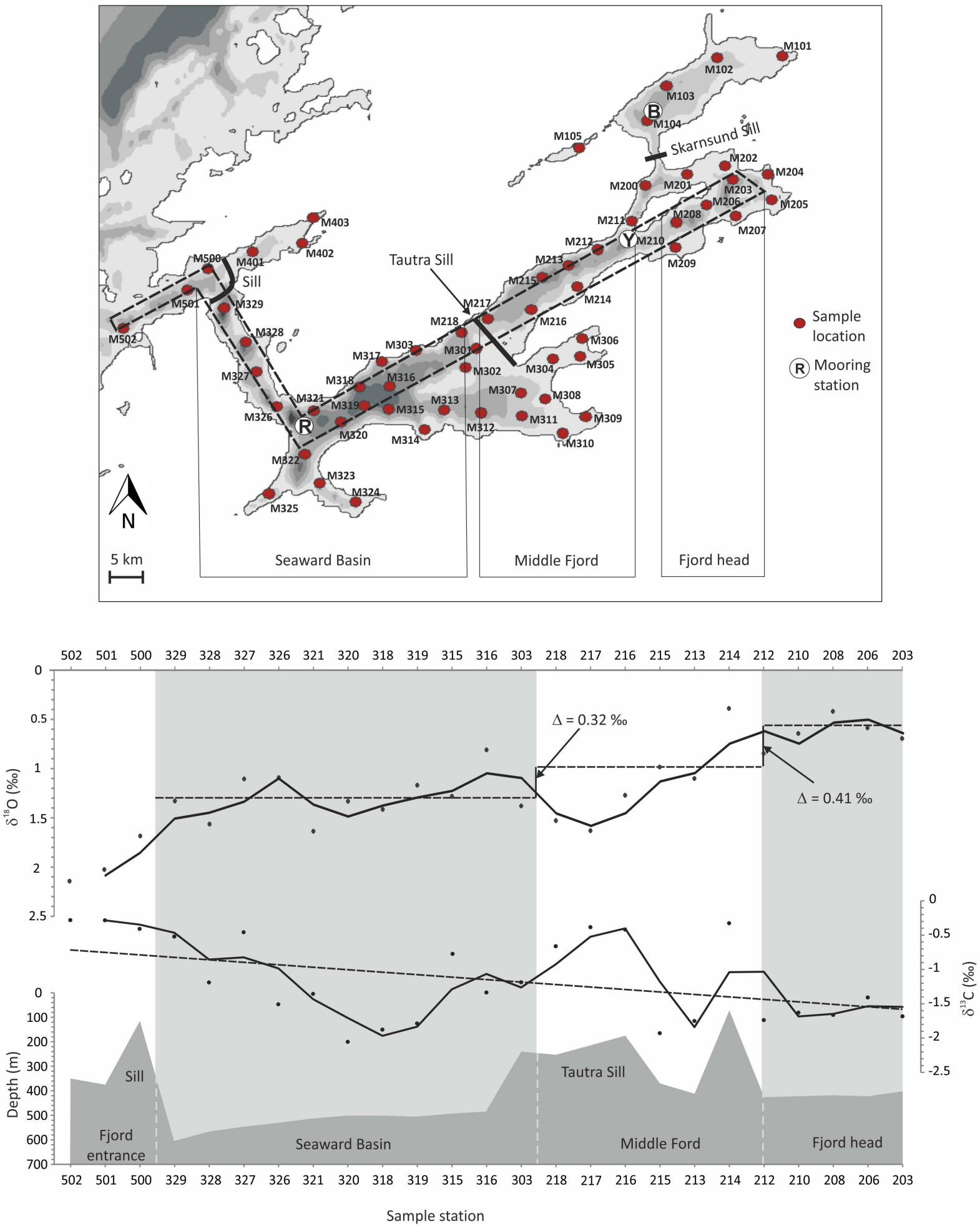

Fig. 4. Top: bathymetric overview with sample locations and fixed mooring stations at Røberg, Ytterøy and Beitstad. The dashed frame marks the sample locations which are displayed below; bottom: cross section of the benthic foraminiferal stable isotope ratios along the fjord axis, top: $\delta^{18} \mathrm{O}$; bottom: $\delta^{13} \mathrm{C}$; black lines correspond to the two point average of the samples. 


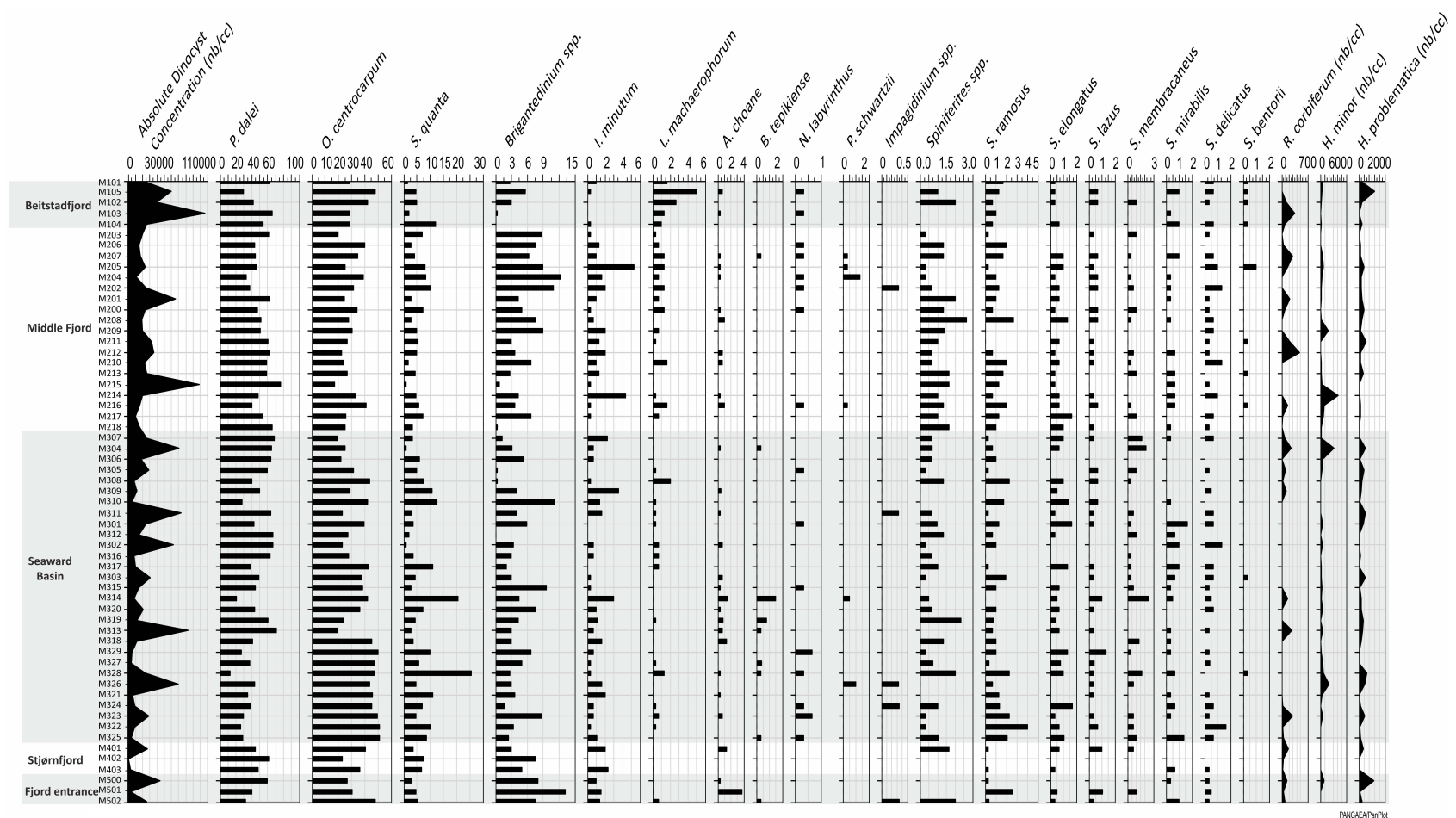

Fig. 5. Dinocyst assemblages in the Trondheimsfjord; relative abundances of cysts are given in \%, total abundance of cysts per sample and other palynomorphs are displayed as concentration in cysts $\mathrm{cm}^{-3}$.

\subsection{Dinocyst assemblages}

Dinocyst concentrations in surface sediments of the Trondheimsfjord (Figs. 5, 6) show a high degree of spatial heterogeneity with a relative increase from the Middle Fjord towards the Beitstadfjord (Fig. 6). According to several previous investigations (e.g. Dale, 1976; de Vernal et al., 2000; Marret and Zonneveld, 2003; and de Vernal, 2007) bulk dinocyst concentrations in sediments are related to several biotic and abiotic factors among which the most important are the sea-surface conditions during production phases of the cysts. After deposition, however, the cyst assemblages can be modified by post-depositional degradation processes related to the oxygen concentration in the bottom and pore water and the species-specific organic wall composition (Zonneveld et al., 1997).

Dinocyst assemblages in the Trondheimsfjord are controlled by several factors such as the history of the coastal water masses, the intensity of the coastal currents at all seasons, precipitation and river discharge, as well as the vertical distribution and the reproductive cycle of the different species. These factors can vary more or less independently and naturally cause large temporal and spatial variations in the recorded cyst abundance (Strømgren, 1974). The spatial heterogeneity of the dinocyst concentrations in surface sediments of the Trondheimsfjord (Fig. 6) reflects the complex and seasonally variable surface hydrology, and the

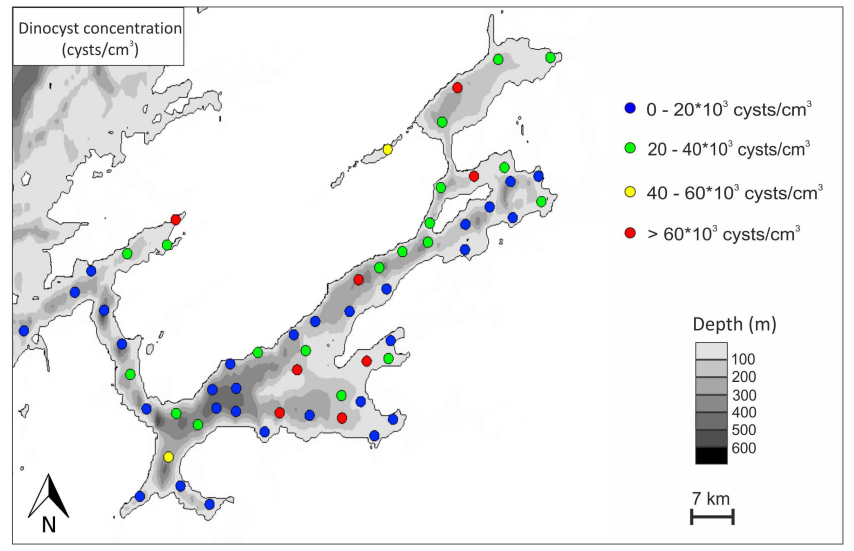

Fig. 6. Dinocyst concentrations $\left(\right.$ cysts $\left.\mathrm{cm}^{-3}\right)$ in surface samples in the Trondheimsfjord.

topographically-steered sediment dynamics (sediment redistribution), dilution by terrigenous material from nearby river inlets and geochemical characteristics in the sediment.

Topographically induced prevalent currents cause a redistribution of fine sediments from shallow settings to the deeper fjord basins. The inner parts of the fjord around the island of Ytterøy and Beitstadfjord are more sheltered than the Seaward Basin. Moreover, tidal surface currents are generally directed towards the fjord head along the fjord's southern 
edge (high tide) with a corresponding countercurrent on the northern edge (low tide) (Fig. 2b). Significant amounts of fresh water and terrigenous material from the rivers Verdalselva and Steinkjerelva are discharged into the inner fjord triggering a strong seasonal stratification of the brackish mixed layer in the fjord basins which favours the spring production of cyst-forming dinoflagellates. Hence, the low cyst concentration at the fjord entrance and the sills might be explained by the surface current circulation and strong bottom currents causing a redistribution of the sediments and the incorporated cysts. As a result of winnowing and sediment remobilization, and a relative increase of the fine particle fraction cyst concentrations in the more sheltered and deep fjord basins are relatively high. Further investigations on sedimentary processes such as local debris and turbidity flows on slopes of the deep fjord basins (Bøe et al., 2003) support our observations on the apparent heterogeneity of cyst accumulation in the Seaward Basin and Middle Fjord.

The dominant species in the Trondheimsfjord are $P$. dalei with a mean relative abundance of $49 \%$ and $O$. centrocarpum (34\%), followed by the two subordinate species Brigantedinium spp. and $S$. quanta (4.83 and $6.02 \%$, respectively) (Fig. 7). All other species contribute less than $2 \%$ to the total assemblage (Fig. 7). Other palynomorphs like Halodinium minor, Hexasterias problematica and Radiosperma corbiferum were identified in the surface sediments with mean absolute concentrations of 474 cysts $\mathrm{cm}^{-3}, 235 \mathrm{cysts} \mathrm{cm}^{-3}$ and 72 cysts $\mathrm{cm}^{-3}$, respectively. The composition of cyst assemblages in the present study is similar to the one described by Dale (1976) from a limited set of sediment samples in the Trondheimsfjord, and to other investigations performed in fjords and shelf environments along the Norwegian coast (e.g. Grøsfjeld et al., 1999; Grøsfjeld and Harland, 2001; and Rørvik et al., 2009). Cyst assemblages in fjords are supposed to reflect the ecological niches of dinoflagellate cysts based on their preferred habitat and feeding strategies. The NMDS method was applied to check for any groupings and (dis)similarities within the study area. The output confirms our observations of a great homogeneity of the data set ( stress $=0.26$ ) impeding any reliable statistically based structuring of the surface sediment dinocyst assemblages in the fjord.

The most abundant species in our data set are adapted to a wide range of temperature and salinity. Pentapharsodinium dalei and $O$. centrocarpum are autotrophic species tolerating large temperature and salinity ranges from ca. $-2^{\circ}$ to $30^{\circ} \mathrm{C}$ and 16 (21 PSU for P. dalei) to $36.7 \mathrm{PSU}$, respectively. Cysts of Brigantedinium spp. and S. quanta belong to the heterotrophic species, both of them tolerating temperatures between $-2.1^{\circ}$ and $30^{\circ} \mathrm{C}$ and salinity between 17 and $37 \mathrm{PSU}$ (Matthiessen, 1995; Marret and Zonneveld, 2003; de Vernal and Marret, 2007). The following discussion will be focused on these species since the in situ production of species with highest abundances is most likely and may be related to recurrent dynamics rather than sporadic events.
The dominance of $P$. dale $i$ in the Trondheimsfjord is probably linked to the high turbidity of the water column and the prevailing surface currents. This relatively small cyst is supposed to get easily stuck on biogenic and lithogenic particles in the water column, leading to a more rapid deposition at the sediment surface than bigger cysts (Dale, 1976). Highest relative abundance of $P$. dale $i$ were observed in the central Seaward Basin, the Middle Fjord and the Beitstadfjord with decreasing abundance towards the fjord entrance (Fig. 8). We assume that the reduced abundance of $P$. dalei at the fjord entrance is caused by the weaker stratification of the water column due to stronger currents and limited riverine input. Moreover, the transport of living and dead cysts over large distances by strong currents at the fjord entrance and in the narrow passage between the entrance and the Seaward Basin (Bøe et al., 2003) constitutes unfavourable conditions for the production and sedimentation of $P$. dale $i$ in this area. Operculodinium centrocarpum shows the opposite distribution with highest abundance at the fjord entrance and in the narrow passage, and lower amounts in the other fjord basins (Fig. 8). This species is considered to be an ubiquitous species that preferentially thrives in warm and saline waters (Matthiessen, 1995; Marret and Zonneveld, 2003; de Vernal and Marret, 2007). The contrary distributions of $P$. dalei and $O$. centrocarpum in spite of similar habitat preferences might be related to their individual stress tolerance and ecological survival strategies. Experimental studies (e.g. Lewis et al.,1985; and Sullivan and Swift, 2003) have shown that cyst production is highly dependent on the water column stratification triggering photosyntetic activity. The stratification of the water column varies seasonally depending on wind patterns, temperature and salinity changes, and river discharge. After the bottom water renewal in late winter/early spring the pycnocline deepens. This triggers the internal mixing of deep bottom water with intermediate waters and increases the availability of nutrients for the dinoflagellates in the upper water layers. Increased temperatures and sunlight intensity in spring and early summer establish the required conditions for autotrophic species and trigger a phytoplankton bloom (Harland et al., 2004; Bagøien et al., 2012). The hydrographic conditions tend to remain stable until early autumn when north-westerly winds trigger another bottom water renewal. Such a general seasonal relationship of the two dinocyst species in fjord environments is confirmed by several studies from the Oslofjord and in the Trondheimsfjord (e.g. Sakshaug and Myklestad, 1973; Strømgren, 1974; Dale, 1976; and Harland et al., 2004). Moreover, Head et al. (2001) and Harland et al. (2004) observed a strong presence of both thecate cells and cysts of the autotrophic species $P$. dalei and $O$. centrocarpum in topographically similar settings during spring.

Cysts of Brigantedinium spp. were observed in maximum amounts in the southernmost side branch of the Seaward Basin at the mouth of the rivers Orkla and Gaula, and at the fjord head close to the island of Ytterøy (Fig. 8). 


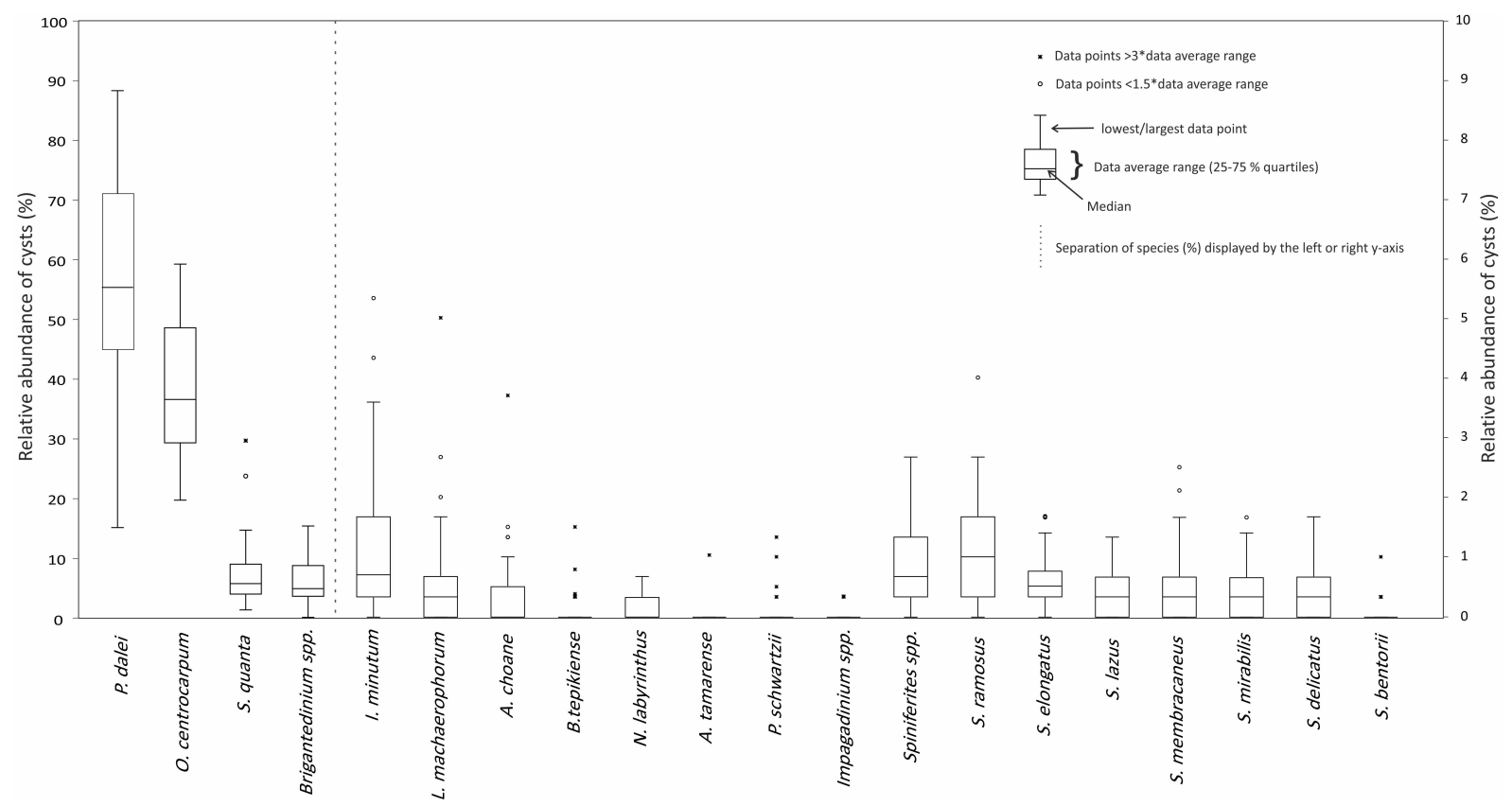

Fig. 7. Distributional ranges (\%) of dinocyst species in the Trondheimsfjord surface sediments using the software package PAST by Hammer et al. (2001).

Selenopemphix quanta occurs preferentially close to river inlets and slightly increases at the fjord entrance (Fig. 8). In areas of relatively low temperature and salinity variability of the surface and intermediate waters the distribution of these two species is considered to be largely controlled by their food requirements linked to the amount of nutrients in the water column, and the presence of diatoms for Brigantedinium spp. Cysts of $S$. quanta have been reported from temperate to subpolar latitudes with highest abundances in upwelling areas where nutrients from deeper water masses are mixed into the surface water layers (Marret and Zonneveld, 2003 and references therein). Obviously, these heterotrophic species thrive best in high-nutrient waters close to river mouths and upwelling areas (Harland et al., 2006). However, other factors also influence their growth rate and postdepositional preservation ability which may significantly alter the spatial distribution of the cysts regarding the time period of 4-20 yr integrated in the investigated surface sediment samples. Cysts of Brigantedinium spp. and $S$. quanta are more sensitive to oxygen exposure than cysts of $O$. centrocarpum and P. dalei (Zonneveld et al., 1997, 2007). The exposure time of dinocysts to oxygen varies with the sedimentation rate, bioturbation and sediment remobilization by bottom currents. High sedimentation rates generally reduce the oxygen penetration in the bottom sediments and thus limit the decay of the cysts (Zonneveld et al., 1997, 2007). The top $2 \mathrm{~cm}$ of sediment analysed for the purpose of this study were still within the oxygen penetration depth, and the observed absolute and relative species abundances at each study site are likely to be modified by post-depositional de- composition. Nevertheless, with regard to the cyst distribution, the relatively higher abundance of the heterotrophic species close to river inlets in spite of changing preservation abilities appears to support our interpretations of the prevalent environmental conditions at time of cyst production.

Halodinium minor and $R$. corbiferum are chlorophycean algae (Price and Pospelova, 2011). Halodinium minor has been previously reported from polar environments by Mudie (1992) and from warm to temperate environments in Australian estuaries by McMinn (1991). Matthiessen (1995) found high relative abundances at the Greenland and Iceland shelf with a random occurrence in the central Greenland Sea and the Norwegian Sea. Radiosperma corbiferum has been recorded in high concentrations from the Baltic Sea, the Barents Sea (Sorrel et al., 2006 and references therein) and the Laptev Sea (Matthiessen, 1995; Kunz-Pirrung, 1999, 1998; Sorrel et al., 2006; Price and Pospelova, 2011). Hexasterias problematica is a Prasinophyceae species (Parke and Dixon, 1964; Price and Pospelova, 2011) and has been recorded from Baffin Bay fjords by Mudie (1992) and in the North Sea region by Cleve (1900). These palynomorphs are linked to low saline/brackish cold surface waters in a marine environment with proximity to river inlets and/or melt water plumes (Matthiessen, 1995; Kunz-Pirrung, 1998; Sorrel et al., 2006; Price and Pospelova, 2011).

The assemblage of palynomorphs in the Trondheimsfjord mirrors the large seasonal range in hydrological conditions and implies a high stress tolerance and fast adaptation of the dominant species. Recent studies (Smayda and Reynolds, 2003) group the species according to their survival strategies 

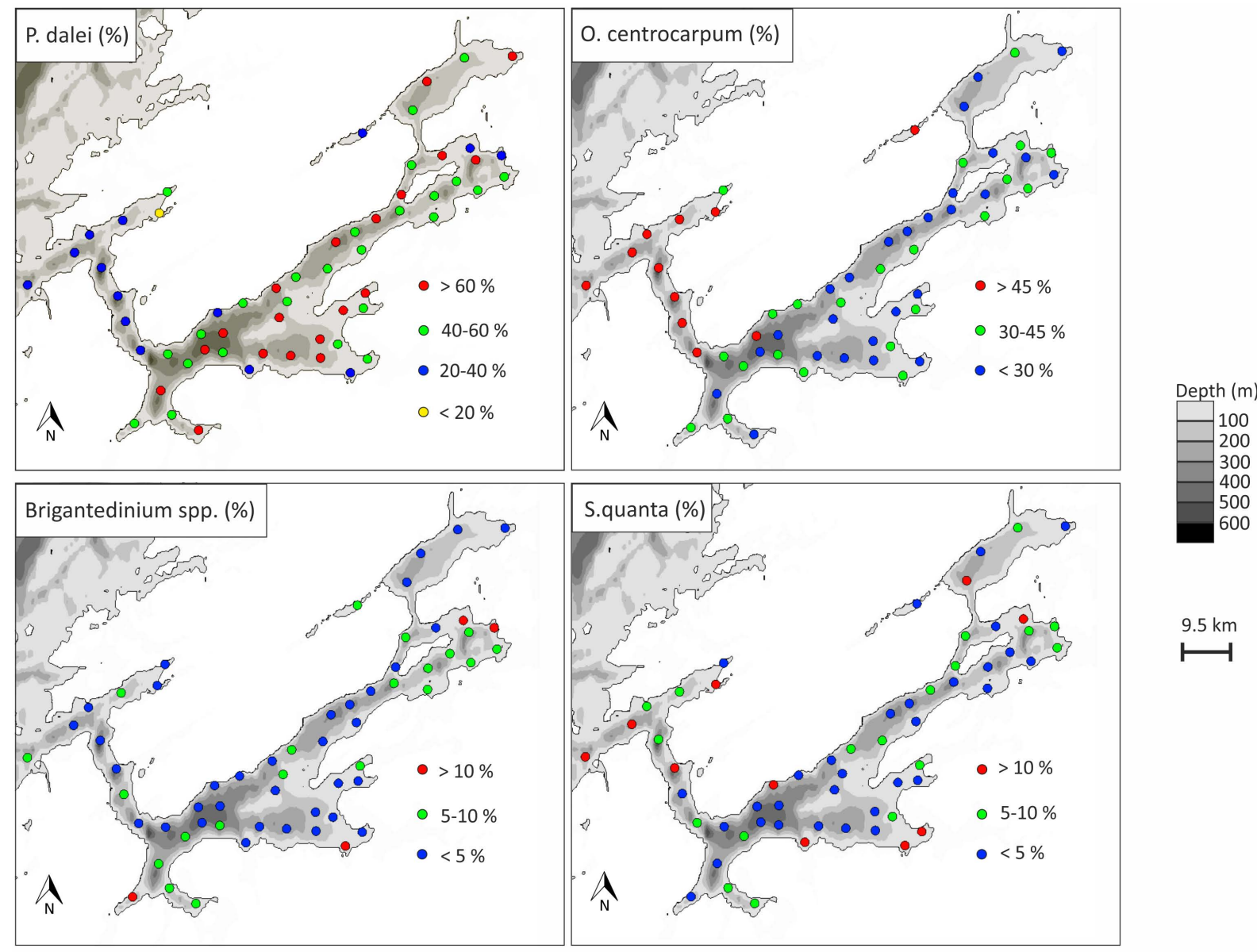

Fig. 8. Relative distribution of the dominant and subordinate cysts in the Trondheimsfjord.

with regard of their tolerance to physical disturbance, light stress and nutrient availability into competitors, stress tolerant species and disturbance tolerant species (Harland et al., 2006). At this stage, even though this hypothesis seems to be applicable to the Trondheimsfjord, the data set does not provide enough information to evaluate survival strategies of the dinoflagellates and their cysts.

\subsection{Anthropogenic impact on the modern surface samples}

Large inputs of untreated wastewater from past industrial (mining, erts shipping, quarries etc.) and agricultural activities impacted the Trondheimsfjord throughout most of the 20th century (Tangen and Arff, 2003 and references therein). Investigations during the years of 2000 to 2003 on the pelagic and benthic ecosystems in the Trondheimsfjord reported by Tangen and Arff (2003) prove that nowadays this anthropogenic input is largely controlled since no indication of a lowered biodiversity or eutrophication has been recorded in the sediments and in the bottom fauna. An evaluation of changes in the dinocyst assemblages in- duced by eutrophication was accomplished in Frierfjord and Brevikfjord in south Norway by Sætre (1997) and in the Oslofjord by Dale et al. (1999). The results show that the pre-industrial assemblages are characterized by the dominance of $P$. dalei and $O$. centrocarpum and relatively low abundance of $L$. machaerophorum which is considered to be highly sensitive to eutrophication. At the beginning of industrial activity the relative abundances of $P$. dalei decreased whereas the cyst abundance of L. machaerophorum remarkably increased (Sætre, 1997; Dale et al., 1999). Regarding the cyst assemblages described in the present study modern surface sediments in the fjord environment appear to reflect pre-industrial-like conditions. Still, we cannot certainly exclude a relative impact of recent industrial and agricultural effluents on the present-day sediments. With regard to the recurrent exchange of the fjord water with the coastal waters we are, however, confident that the modern spatial distribution of benthic stable isotopes and dinocyst assemblages in the Trondheimsfjord provide a credible analogue for further analysis of the Holocene natural climate variability in this area. 


\section{Implications and conclusions}

Based on an extensive and evenly distributed set of surface sediment samples we show that the potential proxy indicators analysed in this study reliably record the complex modern hydrological and environmental setting of the Trondheimsfjord. Both the benthic stable isotope ratios and the dinocyst assemblages very well indicate the spatial variations in marine and fresh water influence across the entire fjord.

The spatial variability of foraminiferal $\delta^{18} \mathrm{O}$ reflects the complex combination of the temperature and salinity structure of the prevalent water masses. Contrary to the dominant role of temperature on the distribution of benthic foraminiferal oxygen isotopic ratios in most open marine surface sediments, our observations indicate that the present-day $\delta^{18} \mathrm{O}$ in the Trondheimsfjord mainly follows the salinity gradient along the fjord axis and essentially records the influence of the increasing supply of brackish river water towards the fjord head.

The spatial variability of benthic $\delta^{13} \mathrm{C}$ in the Trondheimsfjord mainly reflects the marine vs. terrigenous origin of the organic matter at the sediment surface which tends to have an increasingly continental proportion towards the fjord head. Local deviations from this overall trend are related to the complex fjord topography, associated current dynamics and the particular sediment structure at each study site. Winnowing and remobilization of fine-grained organic-rich sediment over topographic highs limit the accumulation of organic matter and explain the difference in benthic $\delta^{13} \mathrm{C}$ between deep and shallow sites.

The cyst assemblages record the hydrographic changes of the Trondheimsfjord that is dominated by a strong seasonality and the decreasing influence of the NAC towards the fjord head. The recurrent bottom water renewal, fluvial input and seasonal stratification of the water column affect the nutrient availability and trigger the production of dinoflagellate cysts depending on their feeding strategy. A potential post-depositional alteration of the original cyst assemblages cannot be excluded but does not appear to be contrary to our observations of several contrasting hydrographic regimes and environments.

In summary, the hydrology of the Trondheimsfjord underlies strong seasonal variations that affect the benthic foraminiferal isotope ratios and the production of dinoflagellate cysts. Even though a seasonal sampling strategy would be most appropriate to determine specific forcing factors in detail, this study proves that benthic foraminifera and dinocysts are suitable tools to study the Holocene climate variability from sediment cores in this fjord environment.
Acknowledgements. This work is a contribution to the CASE Initial Training Network funded by the European Community's 7th Framework Programme FP7 2007/2013, Marie Curie Actions, under Grant Agreement No. 23811. (http://caseitn.epoc.u-bordeaux1.fr/). The Trondheim Biological Station of the Norwegian University of Science and Technology provided temperature and salinity data sets from the fjord mooring hydrological stations. Anne de Vernal (GEOTOP, UQAM) and Christophe Fontanier (BIAF, Université Angers) are gratefully acknowledged for their support and helpful suggestions during the preparation of this manuscript.

Edited by: H. Kitazato

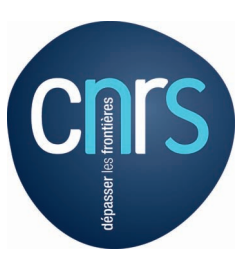

The publication of this article is financed by CNRS-INSU.

\section{References}

Alve, E.: Benthic foraminiferal responses to absence of fresh phytodetritus: A two-year experiment, Mar. Micropaleontol., 76, 6775, doi:10.1016/j.marmicro.2010.05.003, 2010.

Alve, E., Murray, J. W., and Skei, J.: Deep-sea benthic foraminifera, carbonate dissolution and species diversity in Hardangerfjord, Norway: An initial assessment, Estuar. Coast Shelf S., 92, 90102, doi:10.1016/j.ecss.2010.12.018, 2011.

Aure, J., Strand, Ø., Erga, S., and Strohmeier, T.: Primary production enhancement by artificial upwelling in a western Norwegian fjord, Mar. Ecol.-Prog. Ser., 352, 39-52, doi:10.3354/meps07139, 2007.

Bagøien, E., Melle, W., and Kaartvedt, S.: Seasonal development of mixed layer depths, nutrients, chlorophyll and Calanus finmarchicus in the Norwegian Sea - A basinscale habitat comparison, Prog. Oceanogr., 103, 58-79, doi:10.1016/j.pocean.2012.04.014, 2012.

Bauch, H. A., Erlenkeuser, H., Bauch, D., Mueller-Lupp, T., and Taldenkova, E.: Stable oxygen and carbon isotopes in modern benthic foraminifera from the Laptev Sea shelf: implications for reconstructing proglacial and profluvial environments in the Arctic, Mar. Micropaleontol., 51, 285-300, doi:10.1016/j.marmicro.2004.01.002, 2004.

Bemis, B. and Spero, H.: Reevaluation of the oxygen isotopic composition of planktonic foraminifera: Experimental results and revised paleotemperature equations, Paleoceanography, 13, 150160, 1998.

Bøe, R., Rise, L., Blikra, L. H., Longva, O., and Eide, A.: Holocene mass-movement processes in Trondheimsfjorden, Central Norway, Norw. J. Geol., 83, 3-22, 2003.

Cage, A. G. and Austin, W. E. N.: Seasonal dynamics of coastal water masses in a Scottish fjord and their potential influence on benthic foraminiferal shell geochemistry, Geol. Soc. London, Special Publications, 303, 155-172, doi:10.1144/SP303.11, 2008.

Caralp, M. H.: Abundance of Bulimina exilis and Melonis barleeanum: Relationship to the quality of marine organic matter, Geo-Mar. Lett., 9, 37-43, 1989. 
Cleve, P. T.: The plankton of the North Sea, the English Channel, and the Skagerrak in 1898, Kungl. Svenska Vetenskapsakademiens Handlingar, 32, 1-53, 1900.

Corliss, B. H., McCorkle, D., and Higdon, D. M.: A time series study of the carbon isotopic composition of deepsea benthic foraminifera, Paleoceanography, 17, 1036, doi:10.1029/2001PA000664, 2002.

Dale, B.: Cyst formation, sedimentation and preservation: Factors affecting dinoflagellate assemblages in recent sediments from Trondheimsfjord, Norway, Rev. Palaeobot. Palynol., 22, 39-60, 1976.

Dale, B., Thorsen, T. A., and Fjellså, A.: Dinoflagellate cysts as Indicators of cultural eutrophication in the Oslofjord, Norway, Estuar. Coast. Shelf S., 48, 371-382, doi:10.1006/ecss.1999.0427, 1999.

Dale, B., Dale, A. L., and Jansen, J. H. F.: Dinoflagellate cysts as environmental indicators in surface sediments from the Congo deep-sea fan and adjacent regions, Palaeogeogr. Palaeocl., 185, 309-338, 2002.

de Vernal, A. and Marret, F.: Organic-Walled Dinoflagellate Cysts?: Tracers of Sea-Surface Conditions, Mar. Geol., 1, 371-408, doi:10.1016/S1572-5480(07)01014-7, 2007.

de Vernal, A., Henry, M., and Bilodeau, G.: Techniques de Préparation et d'Analyse en Micropaleontologie, Le Cahiers du GEOTOP, 3, Université du Québec à Montréal, Canada, 1996.

de Vernal, A., Hillaire-Marcel, C., Turon, J.-L., and Matthiessen, J.: Reconstruction of sea-surface temperature, salinity, and seaice cover in the northern North Atlantic during the last glacial maximum based on dinocyst assemblages, Can. J. Earth Sci., 37, 725-750, 2000.

de Vernal, A., Henry, M., Matthiessen, J., Mudie, P. J., Rochon, A., Boessenkool, K. P., Eynaud, F., Grøsfjeld, K., Guiot, J., Hamel, D., Harland, R., Head, M. J., Kunz-Pirrung, M., Levac, E., Loucheur, V., Peyron, O., Pospelova, V., Radi, T., Turon, J.L., and Voronina, E.: Dinoflagellate cyst assemblages as tracers of sea-surface conditions in the northern North Atlantic, Arctic and sub-Arctic seas: the new $\mathrm{n}=677$ data base and its application for quantitative palaeoceanographic reconstruction, J. Quaternary S., 16, 681-698, doi:10.1002/jqs.659, 2001.

Eilertsen, H. C. and Skarðhamar, J.: Temperatures of north Norwegian fjords and coastal waters: Variability, significance of local processes and air-sea heat exchange, Estuar. Coast. Shelf S., 67, 530-538, doi:10.1016/j.ecss.2005.12.006, 2006.

Ellingsen, I. H.: Internal tides and the spread of river plumes in the Trondheim Fjord, 1-174, Norwegian University of Science and Technology (NTNU), Trondheim (Norway), 2004.

Epstein, S., Buchsbaum, R., Lowenstam, H. A., and Urey, H. C.: Revised carbonate-water isotopic temperature, Geol. Soc. Am. Bull., 64, 1315-1326, doi:10.1130/00167606(1953)64[1315:RCITS]2.0.CO;2, 1953.

Erga, S. R., Aursland, K., Frette, Ø., Hamre, B., Lotsberg, J. K., Stamnes, J. J., Aure, J., Rey, F., and Stamnes, K.: UV transmission in Norwegian marine waters: controlling factors and possible effects on primary production and vertical distribution of phytoplankton, Mar Ecol.-Prog. Ser., 305, 79-100, doi:10.3354/meps305079, 2005.

Erlenkeuser, H., Spielhagen, R., and Taldenkova, E.: Stable isotopes in modern water and bivalve samples from the southern Kara Sea, Ber. Polarforsch., 300, 80-90, 1999.
Filipsson, H. L., Nordberg, K., and Gustafsson, M.: Seasonal study of $\delta^{18} \mathrm{O}$ and $\delta^{13} \mathrm{C}$ in living (stained) benthic foraminifera from two Swedish fjords, Mar. Micropaleontol., 53, 159-172, doi:10.1016/j.marmicro.2004.05.008, 2004.

Fontanier, C., Jorissen, F. J., Licari, L., Alexandre, A., Anschutz, P. and Carbonel, P.: Live benthic foraminiferal faunas from the Bay of Biscay: faunal density, composition, and microhabitats, Deep-Sea Res. Pt. I, 49, 751-785, doi:10.1016/S09670637(01)00078-4, 2002.

Fontanier, C., Jorissen, F. J., Anschutz, P., and Chaillou, G.: Seasonal variability of benthic foraminiferal faunas at 1000 $\mathrm{m}$ depth in the Bay of Biscay, J. Foramin. Res., 36, 61-76, doi:10.2113/36.1.61, 2006.

Fontanier, C., Jorissen, F. J., Michel, E., Cortijo, E., Vidal, L., and Anschutz, P.: Stable oxygen and carbon isotopes of live (stained) benthic foraminifera from Cap-Ferret Canyon (Bay of Biscay), J. Foramin. Res., 38, 39-51, doi:10.2113/gsjfr.38.1.39, 2008.

Ganachaud, A. and Wunsch, C.: Improved estimates of global ocean circulation, heat transport and mixing from hydrographic data, Nature, 408, 453-7, doi:10.1038/35044048, 2000.

Graham, D. W., Corliss, B. H., Bender, M. L., and Keigwin, L. D.: Carbon and oxygen isotopic disequilibria of recent deep-sea benthic foraminifera, Mar. Micropaleontol., 6, 483-497, 1981.

Grøsfjeld, K. and Harland, R.: Distribution of modern dinoflagellate cysts from inshore areas along the coast of southern Norway, J. Quaternary S., 16, 651-659, doi:10.1002/jqs.653, 2001.

Grøsfjeld, K., Larsen, E., Sejrup, H. P., De Vernal, A., Flatebø, T., Vestbø, M., Haflidason, H. and Aarseth, I.: Dinoflagellate cysts reflecting surface-water conditions in Voldafjorden, western Norway during the last 11300 years, Boreas, 28, 403-415, 1999.

Grossmann, E. L.: Stable isotopes in modern benthic foraminifera: A study of vital effect, J. Foramin. Res., 17, 48-61, 1987.

Hammer, Ø., Harper, D. A. T. and Ryan, P. D.: Paleontological Statistics Software, available at: http://folk.uio.no/ohammer/ past/, 2001.

Harland, R., Nordberg, K., and Filipsson, H.: The seasonal occurrence of dinoflagellate cysts in surface sediments from Koljö Fjord, west coast of Sweden - a note, Rev. Palaeobot. Palynol., 128, 107-117, doi:10.1016/S0034-6667(03)00115-5, 2004.

Harland, R., Nordberg, K., and Filipsson, H. L.: Dinoflagellate cysts and hydrographical change in Gullmar Fjord, west coast of Sweden, Sci. Total Environ., 355, 204-31, 2006.

Head, M. J., Harland, R., and Matthiessen, J.: Cold marine indicators of the late Quaternary: The new dinoflagellate cyst genus Islandinium and related morphotypes, J. Quaternary S., 16, 621636, doi:10.1002/jqs.657, 2001.

Holland, S. M.: Non - Metric Multidimensional Scaling (MDS), available at: strata.uga.edu/software/pdf/mdsTutorial.pdf, 2008.

Holsten, J., Stott, L., and Berelson, W.: Reconstructing benthic carbon oxidation rates using $\delta^{13} \mathrm{C}$ of benthic foraminifers, Mar. Micropaleontol., 53, 117-132, 2004.

Howe, J. A., Austin, W. E. N., Forwick, M., and Paetzel, M. (Eds.): Fjord Systems and Archives, Geological Society London, Special Publications, 344, 2010.

Ingram, B. L., Conrad, M. E., and Ingle, J. C.: Stable isotope and salinity systematics in estuarine waters and carbonates: San Francisco Bay, Geochim. Cosmochim. Ac., 60, 455-467, doi:10.1016/0016-7037(95)00398-3, 1996. 
Jacobson, P.: Physical oceanography of the Trondheimsfjord, Geophysi. Astro. Fluid, 26, 3-26, 1983.

Jansen, E., Slettemark, B., Bleil, U., Henrich, R., Kringstad, L., and Rolfsen, S.: Oxygen and carbon isotope stratigraphy and magnetostratigraphy of the last 2.8 ma: Paleoclimatic comparisons between the Norwegian Sea and the North Atlantic, Proceedings of the Ocean Drilling Program, 104, 255-269, 1989.

Kunz-Pirrung, M.: Rekonstruktion der Oberflächenwassermassen der östlichen Laptevsee im Holozän anhand von aquatischen Palynomorphen, Ber. Polarforsch. 281, ISSN 0176-5027, 281, 1998.

Kunz-Pirrung, M.: Distribution of aquatic palynomorphs in surface sediments from the Laptev Sea, Eastern Arctic Ocean, in LandOcean Systems in the Siberian Arctic: Dynamics and History, edited by: Kassens, H., Bauch, H. A., Dmitrenko, I., and Al, E., 561-575, Springer-Verlag, Berlin, 1999.

Lewis, J., Tett, P., and Dodge, J. D.: The cyst-theca cycle of Gonyaulax polyedra (Lingulodiniuim machaerophorum) in $\mathrm{Cr}$ eran, a Scottish west coast Sea-Loch, in: Toxic dinoflagellates, edited by: Anderson, D. M., White, A. W., and Baden, D. G., Elsevier Science Publishing, 85-90, 1985.

Loubere, P., Jacobsen, B., Klitgaard-Kristensen, D., Husum, K., Jernas, P., and Richaud, M.: The structure of benthic environments and the paleochemical record of foraminifera, Deep-Sea Res. Pt. I, 58, 535-545, doi:10.1016/j.dsr.2011.02.011, 2011.

Mackensen, A., Schumacher, S., Radke, J., and Schmidt, D. N.: Microhabitat preferences and stable carbon isotopes of endobenthic foraminifera: Clue to quantitative reconstruction of oceanic new production?, Mar. Micropaleontol., 40, 233-258, doi:10.1016/S0377-8398(00)00040-2, 2000.

Marret, F. and Zonneveld, K.: Atlas of modern organic-walled dinoflagellate cyst distribution, Rev. Palaeobot. Palynol., 125, 1200, doi:10.1016/S0034-6667(02)00229-4, 2003.

Matthiessen, J.: Distribution patterns of dinoflagellate cysts and other organic-walled microfossils in recent NorwegianGreenland Sea sediments, Mar. Micropaleontol., 24, 307-334, 1995.

McCorkle, D. C., Keigwin, L. D., Corliss, B. H., and Emerson, S. R.: The influence of micorhabitats on the carbon isotopic composition of deep-sea benthic foraminifera, Paleoceanography, 5, 161-185, 1990

McMinn, A.: Recent dinoflagellate cysts from estuaries on the central coast of New South Wales, Australia, Micropaleontology, 37, 269-287, 1991.

Mikalsen, G. and Sejrup, H. P.: Oxygen isotope composition of fjord and river water in the Sognefjorden drainage area, Western Norway. Implications for paleoclimate studies, Estuar. Coast. Shelf S., 50, 441-448, doi:10.1006/ecss.1999.0581, 2000.

Mork, M.: Circulation phenomena and frontal dynamics of the Norwegian Coastal Current, P. Trans. R. Soc. Lond. A, 302, 635647, doi:10.1098/rsta.1981.0188, 1981.

Mudie, P. J.: Circum-arctic Quaternary and Neogene marine palynofloras: Paleoecology and statistical analysis, in: Neogene and Quaternary Dinoflagellate Cysts and Acritarchs, edited by: Head, M. J. and Wrenn, J. H., American Association of Strategic Palynologists Foundation, Dallas, 347-390, 1992.

Mulitza, S., Boltovskoy, D., Donner, B., Meggers, H., Paul, A. and Wefer, G.: Temperature: $\delta^{18} \mathrm{O}$ relationships of planktonic foraminifera collected from surface waters, Palaeogeogr.
Palaeocl., 202, 143-152, doi:10.1016/S0031-0182(03)00633-3, 2003.

Parke, M. and Dixon, P. S.: Revised check-list of British marine algae, J. Mar. Biol. Assoc. UK, 44, 499-542, 1964.

Pettersson, L.-E.: Totalavløpet fra Norges vassdrag 1900-2010 (Rapport nr 39-2012), Oslo, ISBN: 978-82-410-0827-6, 2012.

Penaud, A., Eynaud, F., Turon, J. L., Blamart, D., Rossignol, L., Marret, F., Lopez-Martinez, C., Grimalt, J. O., Malaizé, B., and Charlier, K.: Contrasting paleoceanographic conditions off Morocco during Heinrich events (1 and 2) and the Last Glacial Maximum, Quaternary Sci. Rev., 29, 1923-1939, doi:10.1016/j.quascirev.2010.04.011, 2010.

Polyak, L., Stanovoy, V., and Lubinski, D. J.: Stable isotopes in benthic foraminiferal calcite from a river-influenced Arctic marine environment, Kara and Pechora Seas, Paleoceanography, 18, 1003, doi:10.1029/2001PA000752, 2003.

Price, A. M. and Pospelova, V.: High-resolution sediment trap study of organic-walled dinoflagellate cyst production and biogenic silica flux in Saanich Inlet (BC, Canada), Mar. Micropaleontol., 80, 18-43, doi:10.1016/j.marmicro.2011.03.003, 2011.

Radi, T., Pospelova, V., de Vernal, A., and Vaughn, B., J.: Dinoflagellate cysts as indicators of water quality and productivity in British Columbia estuarine environments, Mar. Micropaleontol., 62, 269-297, doi:10.1016/j.marmicro.2006.09.002, 2007.

Riding, J. B. and Kyffin-Hughes, J. E.: A review of the laboratory preparation of palynomorphs with a description of an effective non-acid technique, Rev. Bras. Paleontol., 7, 13-44, 2004.

Rochon, A., de Vernal, A., Turon, J.-L., Matthiessen, J., and Head, M. J.: Distribution of recent dinoflagellate cysts in surface sediments from the North Atlantic Ocean and adjacent seas in relation to sea-surface parameters, Am. Assoc. Stratigr. Palynol., 35, 1-146, 1999.

Rørvik, K.-L., Grøsfjeld, K., and Hald, M.: A Late Holocene climate history from the Malangen fjord, North Norway, based on dinoflagellate cysts, Norw. J. Geol., 89, 135-147, 2009.

Sætre, M. M. L., Dale, B., Abdullahb, M. I., and Sætre, G. P.: Dinoflagellate Cysts as Potential Indicators of Industrial Pollution in a Norwegian Fjord, Mar. Environ. Res., 44, 167-189, 1997.

Sætre, R.: Features of the central Norwegian shelf circulation, Cont. Shelf Res., 19, 1809-1831, 1999.

Sætre, R.: Norwegian Coastal Current, edited by: Sætre, R., Tapir Academic Press, 2007.

Sætre, R., Aure, J., and Ljoen, R.: Wind effects on the lateral extension of the Norwegian Coastal Water, Cont. Shelf Res., 8, 239253, 1988.

Sakshaug, E. and Myklestad, S.: Studies on the phytoplankton ecology of the Trondheimsfjord. III Dynamics of phytoplankton blooms in relation to environmental factors, bioassy experiments and parameters for the physiological state of the populations, J. Exp. Mar. Biol. Ecol., 11, 157-188, 1973.

Scheurle, C. and Hebbeln, D.: Stable oxygen isotopes as recorders of salinity and river discharge in the German Bight, North Sea, Geo-Mar. Lett., 23, 130-136, doi:10.1007/s00367-003-0133-2, 2003.

Schmiedl, G. and Mackensen, A.: Multispecies stable isotopes of benthic foraminifers reveal past changes of organic matter decomposition and deep water oxygenation in the Arabian Sea, Paleoceanography, 21, 1-14, doi:10.1029/2006PA001284, 2006. 
Schmiedl, G., de Bovée, F., Buscail, R., Charrière, B., Hemleben, C., Medernach, L., and Picon, P.: Trophic control of benthic foraminiferal abundance and microhabitat in the bathyal Gulf of Lions, western Mediterranean Sea, Mar. Micropaleontol., 40, 167-188, 2000.

Schmiedl, G., Pfeilsticker, M., Hemleben, C., and Mackensen, A.: Environmental and biological effects on the stable isotope composition of recent deep-sea benthic foraminifera from the western Mediterranean Sea, Mar. Micropaleontol., 51, 129-152, 2004.

Shackleton, N. J. and Opdyke, N.: Oxygen isotope and paleomagnetic stratigraphy of equatorial Pacific Core V28-238: Oxygen isotope temperatures and ice volumes on a $10^{5}$ and $10^{6}$ year scale, Quaternary Res., 3, 39-55, 1973.

Smayda, T. J. and Reynolds, C. S.: Strategies of marine dinoflagellate survival and some rules of assembly, J. Sea Res., 49, 95-106, doi:10.1016/S1385-1101(02)00219-8, 2003.

Sorrel, P., Popescu, S.-M., Head, M. J., Suc, J. P., Klotz, S., and Oberhänsli, H.: Hydrographic development of the Aral Sea during the last 2000 years based on a quantitative analysis of dinoflagellate cysts, Palaeogeogr. Palaeocl., 234, 304-327, doi:10.1016/j.palaeo.2005.10.012, 2006.

Stockmarr, J.: Tablets with spores used in absolute pollen analysis, Pollen et Spores, 8, 615-621, 1971.

Strømgren, T.: Zooplankton and Hydrography in Trondheimsfjorden on the west coast of Norway, The Royal Norwegian Society of Sciences and Letters, the Museum, 51-60, 1-38, 1974.
Sullivan, J. M. and Swift, E.: Effects of small-scale turbulence on net growth rate and size of ten species of marine dinoflagellates, J. Phycol., 39, 83-94, 2003.

Tangen, K. and Arff, J.: Høvringen wastewater plant and the environmental quality of the Trondheimfjord, OCEANOR Report (Report no. OCN R-23027), Trondheim (Norway), 2003.

Urey, H.: The thermodynamic properties of isotopic substances, Liverside Lecture, 1946.

Vellinga, M. and Wood, R.: Global climatic impacts of a collapse of the Atlantic thermohaline circulation, Clim. Change, 54, 251267, 2002.

Wall, D. and Dale, B.: The resting cysts of modern marine dinoflagellates and their paleontological significance, Rev. Palaeobot. Palynol., 2, 349-354, 1967.

Woodruff, F., Savin, S. M., and Douglas, R. G.: Biological fractionation of oxygen and carbon isotopes by recent benthic foraminifera, Mar. Micropaleontol., 5, 3-11, 1980.

Zonneveld, K. A. F., Versteegh, G. J. M., and de Lange, G. J.: Preservation of organic-walled dinoflagellate cysts in different oxygen regimes: a 10,000 year natural experiment, Mar. Micropaleontol., 393-405, 1997.

Zonneveld, K. A. F., Bockelmann, F., and Holzwarth, U.: Selective preservation of organic-walled dinoflagellate cysts as a tool to quantify past net primary production and bottom water oxygen concentrations, Mar. Geol., 237, 109-126, doi:10.1016/j.margeo.2006.10.023, 2007. 